\title{
APPLICATION OF THE FTA AND ETA METHOD FOR GAS HAZARD IDENTIFICATION FOR THE PERFORMANCE OF SAFETY SYSTEMS IN THE INDUSTRIAL DEPARTMENT
}

\author{
Jolanta IGNAC-NOWICKA \\ Silesian University of Technology
}

\begin{abstract}
:
The paper analyzes the conditions of safe use of industrial gas systems and factors influencing gas hazards. Typical gas installation and its basic features have been characterized. The results of gas threat analysis in an industrial enterprise using FTA error tree method and ETA event tree method are presented. Compares selected methods of identifying hazards gas industry with respect to the scope of their use. The paper presents an analysis of two exemplary hazards: an industrial gas catastrophe (FTA) and an explosive gas explosion (ETA). In both cases, technical risks and human errors (human factor) were taken into account. The cause-effect relationships of hazards and their causes are presented in the form of diagrams in the drawings.
\end{abstract}

Key words: gas hazard, industrial gas installation, hazard analysis, FTA method, ETA method, human factor

\section{INTRODUCTION}

In today's business one of the greatest threats is the possibility of leakage of hazardous substances into the atmosphere, which can cause catastrophic consequences for people, property and the environment. The use of appropriate hazard identification tools provides the opportunity to correctly assess the magnitude of the risk of a technological breakdown, accident or occupational disease at work or major industrial accident. On the other hand, periodic risk assessment allows continuous improvement of security systems in an enterprise.

Gas hazards in the production process include many factors, including: external factors (environmental), technical faults in gas installations and human error (human factor). For each group of factors, appropriate methods of hazard identification and control should be selected.

In enterprises that use gas installations, hazardous agents in the workplace occur mainly in the presence of: compressed gases, combustible gases in the form of gases or liquids, hot air and toxic gases and vapors. In areas where it is produced, used or stored flammable or toxic gases, it is possible to penetrate these gases into the air and create air mixtures [3]. When a sufficient amount of flammable gas above the lower explosion limit or below the upper explosion limit is formed, an explosive mixture rapidly ignites [6]. Under such conditions, any leaks in the gas system or its components, such as gas tanks, valves, regulators, manometers and others, threaten to explode or poison the workers. Other hazards may be associated with external factors such as: high temperature effects on gas system components (eg during fire), improper maintenance of equipment in the installation and control and measurement apparatus [2].
In enterprises where gas appliances are used, a gas hazard signaling system is required. The principle of operation and elements that create the gas signaling system at the workplace are consistent with the fire alarm system. The purpose of such a system is primarily to detect and signal dangerous concentrations of monitored gas. The remaining tasks of the system are to alert employees of potentially explosive and fire hazards (fire protection devices) and to initiate countermeasures to reduce the risk $[1,5]$.

The gas signaling system consists of the following elements: signaling panel, gas sensors (in the form of electrochemical sensors), alarms, manual fire alarm and guard lines. All elements forming the signaling system are subject to mandatory certification.

The gas fire alarm control panel is a decision-making device that coordinates the operation of the entire signaling system. The main tasks of modern signaling panels are:

- receiving signals from attached detectors and manual fire alarm detectors,

- transmission by the transmission equipment of the alarm signal to the monitoring station or to the fire brigade,

- indication of the location of the hazard,

- depending on the functionality, the commissioning of neutralizing devices,

- supervision of the functioning of the whole plant, including control of cooperating fire protection devices and signaling of damage,

- logging events occurring in the system [1].

Activation of the alarm signaling should be initiated within a maximum of 10 seconds after starting the manual fire alarm or after the detector has started. This time is necessary for the exchange of information between the control panel and the fire detectors on the surveillance line [6]. 
Most commonly used alarm devices are acoustic signaling devices or acoustic signaling devices. Sound emitted from the acoustic signal should stand out in the environment. It is recommended that the alarm be continuous or variable frequency and amplitude [4, 9].

All components of the gas signaling system in an industrial plant are operated as intrinsically safe. For the safe operation of the gas system and monitoring system, there is a requirement for periodic calibration of sensors every 6 months. This control guarantees reliable operation of the gas monitoring system and the life of electrochemical sensors from 3 to 5 years $[8,10]$.

\section{CHARACTERISTICS OF SELECTED METHODS OF HAZARD IDENTIFICATION}

In order to maintain the required level of security in an industrial enterprise, the identyfication of all hazards in the workplace is a precautionary measure. There are many methods for identifying hazards in the subject matter literature. Most often, these are retrospective methods such as document analysis, checklists, or accident card analysis. For identifying dynamic dangers (eg gas hazards), prospective methods of hazard identification are most commonly used. They involve identifying threats and anticipating possible threats. These include: change analysis, failure mode and effect analysis (FMEA), gross hazard analysis (GHA), hazard and operability analysis (HAZOP), job safety analysis (JSA), technique of operations review (TOR), total job analysis (TJA). Fault tree analysis (FTA) and event tree analysis (ETA) are often used [7].

In the analysis of technical hazards arising from the operation of the gas installation and auxiliary equipment, it is preferable to use such identification methods as: fault tree method, event tree method, high hazard analysis, failure analysis and their effects, and process hazards analysis.

These methods of identifying hazards due to their specificity have a limited scope for their use. Comparative characteristics for selected gas hazard identification methods are presented in Table 1 . This table summarizes the most important features of the method, the description of the object being analyzed, the process or workstation, and the possible scope of application of the method.

\section{STUDY OF GAS HAZARDS CAUSED BY FTA AND ETA}

Presented in the research article using selected analysis methods was performed for an example gas installation of a selected chemical company. The gas hazard identification process in the investigated object was performed using the fault tree (FTA) and event tree (ETA) tree. These methods may include simultaneous failures of technical components and failures due to human error (human factor). This gives the opportunity for a broader analysis of causal-effect factors that lead to a final event in the form of an accident or technical breakdown.

FTA hazard analysis was carried out on the example of a safety procedure for the operator of a gas installation containing a toxic substance in a hazardous industrial environment with environmental effects. The fault tree method is used here to determine the sequence or combination of factors that are causing the hazard. In this case, it was necessary to identify the peak event for which the cause of the hazard was identified. Created fault tree is a graphic representation of logical event combinations that can lead to a peak event. Based on the analysis of the fault tree, the cause of the hazards was identified. The analysis could only be applied to those foreseeable events, and the relationships between them are relatively simple.

The fragment of the fault tree created is shown in Figure 1 . In the examined case, the peak event is poisoning the population with toxic substance due to the release of large quantities of this substance from the industrial plant to the air. The cause of this event may be unsealing the transmission pipeline or unsealing the gas tank, or a significant leakage of the main valve. In the subsequent sections of the fault tree, the causes of each possible scenario are considered, as shown in Figure 1.

ETA hazard analysis was carried out on the example of a safety procedure for operating the gas system by the operator in potentially explosive atmospheres. In the event tree method, the analysis starts with finding the causes (threatening factors) that lead to the resulting threats. In the event tree schema, the areas of the event header (description of the initiating event) and the event tree (the sequence of possible events) are extracted. In this case, the method allows analysis of complex safety systems and emergency procedures involving human operator. A snippet of the analysis for the operation of the gas system using the event tree method is shown in Figure 2.

Table 1

Characteristics of selected hazard identification methods

\begin{tabular}{|c|c|c|c|}
\hline Method & Short description of the method & $\begin{array}{l}\text { Method of describing an object, } \\
\text { process or workplace }\end{array}$ & Scope of analysis \\
\hline Job Safety Analysis & $\begin{array}{l}\text { Enables you to identify hazards associated } \\
\text { with work procedures }\end{array}$ & $\begin{array}{l}\text { Based on tasks performed at the } \\
\text { workstation }\end{array}$ & Technical object, man \\
\hline $\begin{array}{l}\text { Hazard and Operability } \\
\text { Studies }\end{array}$ & $\begin{array}{l}\text { Allows you to identify deviations from the } \\
\text { intended function, which can lead to hazards }\end{array}$ & $\begin{array}{l}\text { Based on the physical properties } \\
\text { of the analyzed elements }\end{array}$ & Technical object \\
\hline Fault Tree Analysis & $\begin{array}{l}\text { It leads to identifying the causes of hazards - } \\
\text { the hazard factors and shows their logical } \\
\text { connections, which may lead to the hazard }\end{array}$ & $\begin{array}{l}\text { Determining events whose combi- } \\
\text { nations lead to a peak event }\end{array}$ & Technical object, man \\
\hline Event Tree Analysis & $\begin{array}{l}\text { Allows you to analyze the alternate effects } \\
\text { of a specific event causing a hazard }\end{array}$ & $\begin{array}{l}\text { A sequence of events leading from } \\
\text { the initiating event to the hazard }\end{array}$ & Technical object, man \\
\hline
\end{tabular}

Source: [7]. 


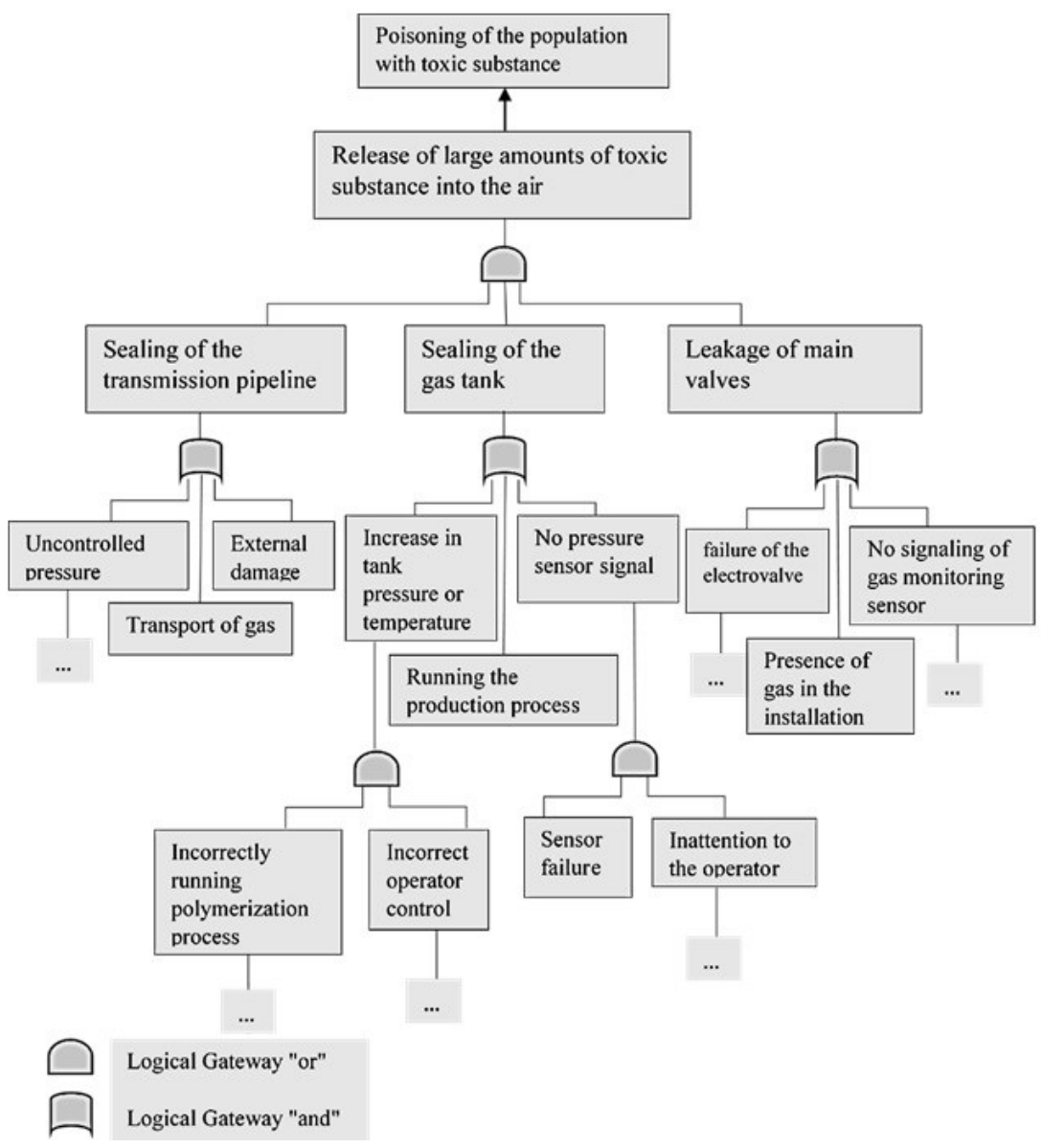

Fig. 1 Analysis of the causes of threats by the FTA method (fragment of the fault tree for the threat of industrial catastrophe) Source: own elaboration.

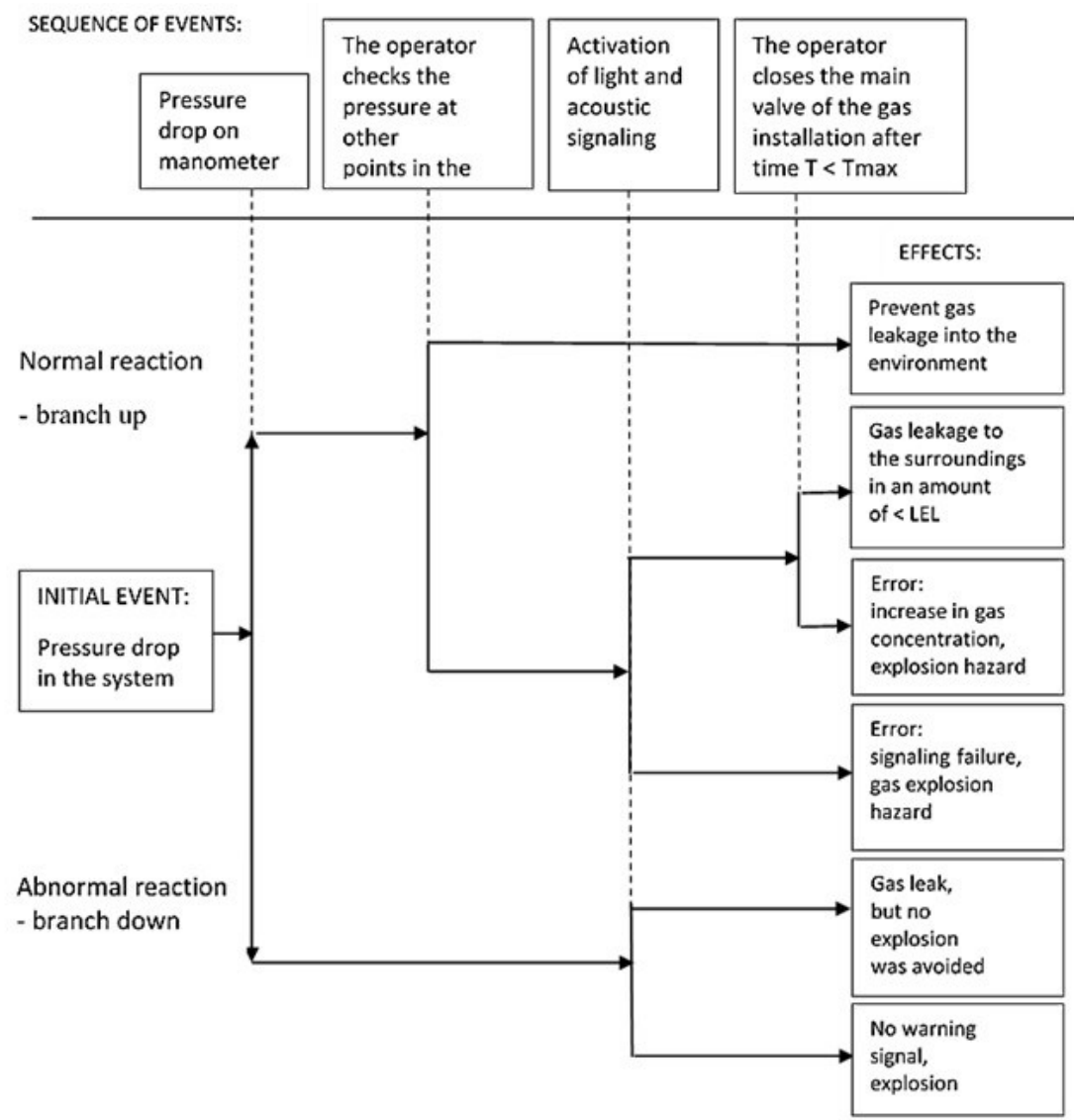




\section{CONCLUSION}

The use of appropriate hazard identification methods can be used to design effective procedures for safe handling of the process. The use of FTA and ETA methods leads to a detailed analysis of the hazards and their causes, thus improving the gas safety systems. In addition, the analysis of two exemplary hazards (the threat of industrial toxic gas catastrophe and the risk of explosion of explosive gas) has shown the link between technical causes and human errors. This allows for the development of more efficient procedures for safe processing in the technological process to improve the gas safety system in a given plant.

In the two cases discussed above, the level of technical hazards is most affected by the degree of reliability of gas safety signaling systems and the appropriate equipment in control and measurement equipment. All components of the gas hazard signaling system should clearly indicate the unsealed state of the system and signal the state by sound signal too.

On the other hand, errors occurring in the process of performing tasks often come from the operator's loss of control over the threat or its own behavior (human factor). In particular, the causes of human error in the work process can be: human factors malfunction, difficult and dangerous tasks, social patterns of conduct, negligence and breaking rules. Circumstances accompanying human error are most often: lack of training, insufficient knowledge, low work discipline, lack of skills and experience, failure to observe production technology, insufficient motivation for safe conduct.

\section{ACKNOWLEDGEMENTS}

This article was prepared within the statutory research titled "Methods and tools for improving products and services on the selected examples" work symbol 13/030/BK_17/0027 performed at Silesia University of Technology, Institute of Production Engineering.

\section{REFERENCES}

[1] K. Chmielewski, „Zasady stosowania stacjonarnych systemów detekcji gazów", Ochrona Mienia i Informacji, no. 4, pp. 69-71, 2011.

[2] J. Ignac-Nowicka, „Air pollution monitoring at the workstand and in the ambient air", Molecular and Quantum Acoustics, vol. 22, pp. 113-121, 2001.

[3] J. Ignac-Nowicka, „Monitorowanie mieszanin gazowych dla bezpieczeństwa procesu produkcji acetylenu", Studies \& Proceedings of Polish Association for Knowledge Management, vol. 40, pp. 170-180, 2011.

[4] J. Ignac-Nowicka, „Zastosowanie sensorów w inżynierii bezpieczeństwa dla rozwoju inteligentnej specjalizacji", in Bezpieczeństwo jako determinanta doskonalenia systemu zarzqdzania organizacjami, M. Górska and E. Staniewska, Eds. Częstochowa: Wydawnictwo Wydziału Inżynierii Produkcji i Technologii Materiałów Politechniki Częstochowskiej, 2016, pp. 80-89.

[5] R. Kalinowski, Monitorowanie zagrożeń. Siedlce: Wyd. Akademii Podlaskiej, 2003.

[6] PN-EN 1127-1:2001 Atmosfery wybuchowe. Zapobieganie wybuchowi i ochrona przed wybuchem. Pojęcia podstawowe i metodologia, Polski Komitet Normalizacyjny, 2001.

[7] R. Studenski, Organizacja bezpiecznej pracy w przedsiębiorstwie. Gliwice: Wydawnictwo Politechniki Śląskiej.

[8] M. Świerżewski, „Urządzenia elektryczne w przestrzeniach zagrożonych wybuchem", Miesięcznik Elektro. info, no. 9/10, pp. 8-12, 2007.

[9] A. Wójcik, Mechaniczne i elektroniczne systemy zabezpieczeń. Literatura fachowa dla firm i instytucji. Warszawa: Wydawnictwo Verlag Dashofer, 2004.

[10] W. Nawrocki, Sensory i systemy pomiarowe. Poznań: Wydawnictwo Politechniki Poznańskiej, 2006.

\footnotetext{
dr inż. Jolanta Ignac-Nowicka

Silesian University of Technology

Faculty of Organization and Management

Institute of Production Engineering

ul. Roosevelta 26, 41-00 Zabrze, POLAND

e-mail: jolanta.ignac-nowicka@polsl.pl
} 